\title{
The Role of Space in the Creation of the Social Capital of Sofia Students Before the Novel Coronavirus Pandemic
}

\author{
Lucien Peters \\ Department of Economic Sociology \\ UNWE, Sofia
}

\section{Ролята на пространството в изграждането на социален капитал \\ на софийските студенти преди коронавирусната пандемия}

\author{
Люсиен Питърс \\ Катедра „Икономическа социология“ \\ УНСС, София
}

\begin{abstract}
Author Note
Lucien Peters is a guest lecturer in the UNWE International Business Master's program.

The author has no known conflict of interest to disclose.

Correspondence concerning this article should be addressed to Lucien Peters. Email:
\end{abstract} lucien_peters@hotmail.com

\section{Бележки за автора}

Люсиен Питърс е гост -лектор в магистърска програма „Международен бизнес“, УHCC.

Авторът декларира, че няма потенциален конфликт на интереси с авторството и публикуването на тази статия.

Адрес за кореспонденция с автора: Email: lucien_peters@hotmail.com 


\begin{abstract}
The paper starts from the notion that the social capital of young persons is an essential part of their well-being and an individual's success in life and society. It presents ethnographic research of the role of urban and regional space as one of the factors relevant to the creation of young people's social capital. The period of research is 2014-2020, until the beginning of the novel coronavirus pandemic in late February 2020. The principal research method is longitudinal ethnographic participant observation in a higher education setting in Sofia, complemented by semistructured interviews and life histories of informants, gathered in informal settings, with members of the post-1980 generations. Informants were aged 19-36, of both genders, and all were known to the enquirer for periods ranging between two and seven years. Their socialization and education took place largely in post-Communist times. The ethnographic observation examines the geographical environment of students' lives, as the space where life takes place is a key factor for the quality of youth people's lives and well-being. Their homes, hometowns, educational institution, leisure pursuits; their potential contacts with other cultures, and other factors which may have emerged during observation, and which may have contributed to the formation of students' social circles and their attitudes towards civic life, have been examined.
\end{abstract}

Keywords: space, social capital, students, well-being, ethnographic participant observation

\title{
Резюме
}

Студията застьпва тезата, че социалният капитал на младите хора е съществена част от тяхното благосъстояние и от успеха на личността в живота и обществото. Представени са резултати от серия етнографски изследвания на ролята на градското и регионалното пространство като един от факторите за създаването на социален капитал на младите хора. Периодът на изследване е 2014-2020 г., до началото на коронавирусната пандемия в края на февруари 2020 г. Основният метод на изследване е лонгитюдно етнографско включено наблюдение в университетските среди в София, допълнено от интервюта с респондентите и анализ на техните биографични разкази. Емпиричният материал е събиран в неформални условия. Респондентите са представители на поколенията след 1980 г. на възраст 19-36, от двата пола. Наблюдението върху тях трае от две до седем 
години. Сравнително малка група от 15 респонденти е наблюдавана и изследвана в пълния период на изследването - седем години. Социализацията и образованието на избраната група респонденти се осъществява предимно в посткомунистическите времена. Етнографското наблюдение изследва географската среда на живота на студентите, тъй като пространството на живеене е ключов фактор за качеството на живота и благосъстоянието на младите хора. Изследвани са техните домове, родни градове, образователни институции, места за занимания за свободното време. Също и местата за осъществяване на потенциални контакти с други култури и други фактори, които се появяват в периода на изследването и допринасят за формирането на социалните кръгове на студентите и отношението им към гражданския живот. Установени са няколко пространствени въздействия и последици за изграждането и поддържането на социалния капитал сред софийските студенти. В светлината на изследователските резултати, студията стига до заключението, че пространствените аспекти, както в макромащаб (регионален и национален), така и в микромащаб (градски квартали), оказват влияние върху поддържането и обхвата на социалния капитал във времето.

Ключови думи: пространство, социален капитал, студенти, благополучие, етнографско наблюдение 


\section{THE ROLE OF SPACE IN THE CREATION OF THE SOCIAL CAPITAL OF SOFIA STUDENTS BEFORE THE NOVEL CORONAVIRUS PANDEMIC}

The paper starts from the notion that the social capital of youth people is an essential part of their well-being and an individual's success in life and society. While this paper received its final editing, the Novel Coronavirus pandemic profoundly impacted civic and economic life in Europe, including Bulgaria. I conducted a quick survey among my informants, to see whether and how their socializing patterns and well-being had changed when this crisis took hold in Bulgaria. Informants stated that they had taken preventive measures concerning the scope and frequency of their social contacts. They had limited their in-person social interaction to a handful of members of their immediate family, including parents and siblings, and partners or spouses, as appropriate and stopped all in-person contacts with grandparents and other members of the extended family, especially those aged 60 or more, as these were perceived to be at a higher risk grave illness than younger persons. In-person contacts largely have been replaced by online or telephone contacts, these having been said to have become much more frequent than usual. Informants stated, however, that virtual socializing was not a good substitute for inperson meetings, with some informants indicating that they suffered from depressive moods after a few weeks of externally- or self-imposed restrictions on their in-person socializing.

It quickly became clear that the "COVID-19" public health crisis has significantly influenced the well-being and development of young persons, including the informants of my research. The comparatively high level of social isolation significantly impacted the geographical scope of their everyday life. Future large-scale research of the role of space and virtual space in the creation and maintenance of social capital under government-imposed movement restrictions could reveal further important characteristics of youth socializing in a restrictive public health environment.

\section{Methodological notes}

The paper presents ethnographic research of the role of traditional space as one of the factors in the creation of young people's social capital before the health crisis of 2020. 
The research has been conducted in $2014-2020^{1}$ The principal research method is longitudinal ethnographic participant observation in a higher education setting in Sofia. This was complemented by semi-structured interviews and informants' life histories, gathered in informal settings, with members of the post-1980 generations - mainly Sofia students and young Sofia university graduates.

In keeping with ethnographic terminology, the students and graduates are referred to as 'informants' in this context. Informants were aged 19-36, of both genders, and all were known to the enquirer for between two and seven years. Some of them were university students during some or all of the period of observation, and some had graduated from university at some point after the year 2000 , i.e. they all had their socialization and education largely in post-Communist times.

Even though only a comparatively small group of 15 informants (some dropped out later during the observation period) was observed and followed intensively over two to seven years, the social anthropology emphasis of this paper on deep, rather than wide-ranging sampling aims to give a complete and very intimate insight into the lives of the informants.

The ethnographic observation approach examines the geographical environment of students' lives as the space where life goes is a key factor for the quality of youth people's lives and well-being. Their homes, hometowns, educational institution, leisure pursuits; their potential contacts with other cultures, and any other factors which may emerge during observation, and which may contribute to the formation of students' social circles and their attitudes towards civic life has been examined.

In my ethnographic observation in Bulgaria, I have distinguished between two levels of spatial settings:

- A macro-spatial level which extended from students' hometowns to the site of their

\footnotetext{
${ }^{1}$ In 2014, I started taking an interest in Bulgarian university students and their socializing patterns, as I had been a supervisor of several Bulgarian graduate trainees at the European Union (EU) institution where I worked. That same year, I had been invited as a lecturer at the US Fulbright Summer School in Pravetz, Bulgaria, where a group of some 60 students from Bulgaria and several foreign countries came together to study a variety of social science topics. Since 2015 I have also lectured occasionally at the Sofia-based 'University of National and World Economy (UNWE)' in their International Business Master's program. This increased the depth and frequency of my contact with students in Sofia, and this experience prompted me to engage in a long-term ethnographic observation of these students.
} 
respective universities, and the place of residence of family members living outside of students' hometowns, as well as places of residence of close friends.

- A micro-spatial level that was centered around the neighborhoods of the universities and student residences in Sofia.

\section{Theoretical framework}

The 18th-century economic geographer Heinrich von Thünen (Von Thünen, 1826) would have found the location of Bulgarian cities of great interest, as the distances between the major cities at almost-uniformly set multiples of 50 kilometers would have gone some way in confirming his 'central place' theory, which - as later elaborated on by Walter Christaller (Christaller, 1933) - holds that mankind organizes its settlements so that people can conveniently be visited, and goods can be traded with an efficient mode of transportation over an economically reasonable distance.

If we follow the central place theory of economic geography, we find an important human element, namely the wish to maintain regular contact with suppliers and purchasers, as well as members of one's various social capital circles. As family-based or family-derived business contacts were, and still are, quite common - especially in smaller countries like Bulgaria, a causal link between economic and human geography becomes quite plausible in this context.

One can only hope that contemporary social geographers (Hörschelmann et.al., 2008) will examine more closely how economic geography patterns drive human interaction and social capital formation, and perhaps vice-versa. For now, we must content ourselves with the relevant work of a few social geographers, and with the early work of Rutten, Westlund, and Boekema (Rutten, et al, 2010) who reminded us that hitherto, not enough had been written yet about the interaction between space and social capital.

Urban planners like Rutten et.al. found that distance is an important factor in maintaining social capital over time, as the frequency of interaction between members of social capital circles is inversely correlated to distance.

What these researchers focused lesson was how the structure of social capital circles might change over time within certain spatial settings; how often, and why. 
Another question to ponder is whether and how distance impacts the creation, co-existence, and maintenance over time of multiple, discrete social capital silos in separate places and what this does to bridging capital. In social capital research, bridging capital is seen as a less tightly-knit form of social capital than bonding capital, which usually consists of a select few long-term friends and members of one's immediate family. In abridging capital context, additional questions arise about the importance of distance and time on possible intersects between geographically disparate social silos - intersects which themselves may or may not be timelimited and purpose-dependent.

One can hope that both large-scale and longitudinal verification of possible geographic influences on the formation and maintenance of bonding and bridging social capital will be undertaken at some point, as this would widen the social capital debate towards one which includes geographic and transportation factors more systematically.

While an in-depth analysis of the above-mentioned factors of geographic distance versus social capital goes beyond the scope of the present paper, some of my informants provided some initial elucidation in this regard.

If we believe Hörschelmann and Stenning (2008), the localization of social interaction and the identification and analysis of the spatial construction of social webs at the intersect of anthropology and geography is an essential pre-condition for an ethnographer's deep understanding of what motivates people to live and assemble in any given place, and for understanding the results of this social interaction.

More specifically, the spatial dimension of social capital is an area of research that started in earnest only in 1999 with Westlund's early work on networks and territory, though he initially focused more on the costs and economic rewards of maintaining social networks for business purposes (Westlund, 1999). As mentioned above, he cooperated with Rutten and Boekema in more broadly examining how social capital is formed and maintained in geographic space, while focusing on the importance of proximity and time in the evolution of social capital within macro space, but not micro space (Rutten et. al., 2010).

The Rutten, Boekema, and Westlund study found that geographic proximity is directly related to the density of social relations, with initially already weak ties among members of a 
social network being especially dependent on proximity for their sheer survival.

Yet, here again, Westlund and his colleagues focus more on economic costs and benefits of social networks, and not so much on other potential costs and benefits, such as cognitive and emotional impacts, including the creation and maintenance of group involvement in civic life, for instance.

In light of the above earlier research about space and social capital, I reserved within my seven-year ethnographic observation of Sofia students a major place for the spatial analysis of the students' social interaction.

\section{Research revelations about the lives of ethnographic informants}

My research about young Bulgarians revealed some notable characteristics of their lives:

1. Their beliefs and attitudes are still shaped to some extent by Bulgaria's Communist past, and specifically by the narratives about that time that their parents and grandparents transmitted to them, e.g. 'Careful whom you trust'; 'Look after yourself first, then after others', and 'Family always comes first.

2. They were very proud of the Bulgarian nation and its culture, but not of the Bulgarian State and its institutions.

3. They were disappointed by the outcome of the economic and political changes of 1990, as they felt that old, corrupt networks from Communist times still dominated the functioning of the state.

4. They showed limited interest in participating in civic and political life, and they voted only sporadically in elections.

5. They had a dynamic social life, but this life took place in discrete silos of social capital, which seemed to have few if any, connecting points between them.

6. Their social circles were largely organized in geographically and purpose-driven distinct settings.

7. They stated that they would be more active in urban civic life if there was stronger leadership within student groups, and within civic organizations which were worthy of their trust, and which could demonstrate their usefulness in 'cleaning up the State'. 
Most importantly, in the context of this article, the formation and maintenance of students' social capital circles was said by my ethnographic informants to be influenced by spatial considerations, namely distance and ease of access, mostly within Sofia, but also between Sofia and their hometowns. Likewise, the importance of spatial location and visibility of public institutions and NGOs in Sofia was also highlighted by many students, when they explained which factors might trigger their interest and participation in civic life.

In light of the importance my informants attributed to their ability to visually absorb and process places, persons, and behaviours in public space - especially when queried about factors that trigger their interest in civic and political life, the analysis of student movements within an urban micro-space becomes relevant to my research.

But first, the analysis of social interaction in specific Sofia neighborhoods needs to be placed in the context of Sofia's spatial position within Bulgaria. Indeed, several informants felt that Sofia, as a capital city, was less than ideally placed within Bulgaria's territory to create citizen interest in national civic and political events. Informants with close ties to other large cities in Bulgaria were especially likely to dispute Sofia's role as the national capital, as they either felt that it was comparatively insignificant in historical terms (e.g. informants with family ties to the ancient cities of Plovdiv or Veliko Tarnovo), or just too distant towards the west of Bulgaria (e.g. informants with close ties to the centrally-located city of Stara Zagora, or with family links to the large Black Sea coastal cities of Varna or Burgas).

\section{Urban versus rural social capital}

Sofia is one of six large and economically important cities in Bulgaria. These six urban areas taken together represent about two-thirds of the country's economic output, and around half of the national population (BSI, 2016).

At the same time, the demographic age pyramid in these urban centers remains relatively cylindrical, indicating a fairly even distribution of the age strata. Outside of the urban centers, the age pyramid is increasingly sharply inverted, with an ever faster-aging population, and even fewer young people (BSI, 2017).

These regionally disparate demographic data appear to have an impact on the overall civic engagement of young persons in Bulgaria, in that young Bulgarians in rural areas remain 
under a stronger family and peer influence than their urban counterparts, especially when it comes to political leanings and interest in civic life.

Informants originating from small towns, and maintaining close family links to such towns, stated that family, primary school friends, and other local persons with some importance in their families' lives still played an important role in shaping their views about local politics.

The continued power and local influence of the Arendatori, i.e. the former collective farm managers who continue to manage much of local agricultural production in smaller towns - nowadays on behalf of largely absent landowners, has been mentioned by Giordano and Kostova (2013) as an important factor in shaping local politics and economic outcomes.

The same is true for some of my informants' beliefs regarding local power structures and influences in their hometowns. Anna, Aleks, and Stefan for instance take a close interest in their, respectively north-western and central, Bulgarian home towns' political life and might consider being one day candidates for local political office, mostly due to their parents already being prominent, publicly visible residents of these towns. They are well aware of the need to 'get along' with local agricultural and business managers and owners who wield a lot of local power.

Ralitsa for her part is interested both in local politics in Sofia and in the Dobrich area in far north-eastern Bulgaria, where some of her immediate family originate from.

Informants confirmed that in rural areas and smaller towns there is a strong interest in local politics, across all age segments, while national politics appear to play a subordinate role. Stefan and Paula, for example, stated that in the north-central Lovech district, where their families hail from, former agricultural cooperative managers and their families still play a role in shaping the political views of rural residents, especially those of the older generations.

In addition, rural residents, including the younger generations, participate to a great extent in local cultural activities, including some hosted by the Chitalishte cultural centers which survived the post-Communist budget reductions, thus maintaining strong bridging capital across their home towns and villages.

This was confirmed by informants Vali who mentioned a regular program of cultural 
activities in her hometown of Etropole, and by Paula and Stefan who both made similar statements about local cultural cohesion being promoted by folkloric and musical events in Lovech, which was said to be small enough - despite its status as a district capital, so that "everybody knows everybody'.

It is only in mid-size and larger Bulgarian cities, such as Stara Zagora (population 150,000 ) or Varna (population of 400,000) that the maintenance over time of location-derived bridging capital seems to become more difficult. Indeed, expatriate informant Maria mentioned that she keeps in touch with only a couple of her high school friends who remained in the Varna region, but that even at the level of her parents' neighborhood in the western suburbs of Varna, she never had many neighborhood-derived social contacts, other than one or two immediate neighbors.

Likewise, informants Resi and Slavi from Stara Zagora stayed in touch with a handful of primary and high school friends who remained in those cities but felt that they never built larger, location-derived circles of friends across those cities, other than with immediate neighbors' children. Resi did, however, mention that central Stara Zagora's layout is still compact enough to 'come across someone you know when you stroll through the city center'.

Drawing on the statements related by my informants from towns ranging in size from 12,000 (Etropole); 40,000 (Lovech); 150,000 (Stara Zagora), to over one million (Sofia), one early indication related to town size specificity in social capital construction and maintenance appears to be that, somewhere between the size of Lovech and that of Stara Zagora, the hurdle between easy and more difficult social capital construction and maintenance rises significantly, especially concerning cross-town bridging capital, i.e. social circles outside of the immediate neighborhoods of their parents or grandparents' residence. This is a micro-spatial topic meriting more comprehensive research in the future.

As alluded to earlier, certain informants had some reservations in accepting Sofia as the historically-grown capital of Bulgaria. While Sofia has indeed been Bulgaria's capital since the end of the Ottoman occupation of Bulgaria in 1879, some of the informants I talked to at Veliko Tarnovo University in 2016, for instance, considered Sofia a rather arriviste and nouveau-riche capital, with limited historical legitimacy as the Bulgarian capital. 
This sentiment was echoed by informants from Lovech, Stara Zagora, and Pleven. Plovdiv with its three thousand years of urban history was considered by some informants to be a more bona fide capital for Bulgaria than Sofia.

Even though Sofia's current economic and political importance was universally acknowledged by informants, its validity as a historically-grown and thus widely-accepted capital city was questioned, including by expatriate Bulgarians I talked to. This historic and culturally-based emotional distance, combined with the geographical distance between Sofia and the other major cities in Bulgaria, appears to have amplified the sense of remoteness and alienation which many non-Sofia native informants said to feel between their hometowns and the center of power in Sofia.

The emotional distance to the capital city also appeared to impact the informants' acceptance of Sofia-based political institutions as being concerned for, and representative of, the entire country. Veliko Tarnovo informant Radi pointed out that Sofia's location in the far western part of Bulgaria - compared with the relatively central location of her hometown of Veliko Tarnovo (the historical capital of Bulgaria), further weakened its claim to be a 'proper' capital for Bulgaria.

Expatriate informant Vanya stated that many people in her south-eastern hometown of Yambol, for instance, 'cannot identify with Sofia as an important city in their lives'.

All informants agreed that bad transportation links between Sofia and most other Bulgarian cities, except Plovdiv, also had an impact on people's perception that Sofia is in 'another world'.

Thus it appears that informants' statements confirm the importance of the interplay of geographic distance and an emotional sense of proximity, which was demonstrated inter alia by Lawton et.al. (1994). In my ethnographic observations, this appeared to play an important socio-psychological role in non-Sofia native students' degree of interest in national civic and political life. Overall, local civic and political life in informants' hometowns seemed to dominate over its equivalent in Sofia, except for Ralitsa's shared interest in the Dobrich area and Sofia politics.

\section{Sofia urban space and social capital}


For a capital city of some 1.3 million inhabitants, Sofia is comparatively compact, with a width of the total urban area of roughly 9 kilometers, both in a north-south and in an east-west direction.

Most Sofia informants stated that the city center, at least in their mind, is bounded in the west and south-west by Gotse Delchev Boulevard, and in the southeast and east by Nikola Vaptsarov boulevard, which becomes Peyko Yavorov boulevard, as it cuts right through the middle of the large city park, the Borissova Gradina. To the north, Sofia's central train station and the train tracks which lead to it towards the west and the east, provide both a visual and a mental boundary to the city center, as only a handful of major over- and underpasses allow a continuation of one's journey to the north and north-east, if one comes from the center. This central area fits well into a circle of some 4 kilometers across.

At the core of the area thus defined, one finds government and cultural buildings; the commercial and entertainment area, including a pedestrian street of recent creation, Vitosha boulevard, which runs on a north-south axis, as well as a mid-size park hosting the massive NDK national cultural and conference center - one of the largest of its kind in Europe.

NDK Park continues towards the aptly named South Park, the southern boundary of which leads us to the above-mentioned outer limit of central Sofia on Gotse Delchev and Vaptsarov boulevards. The historical center, with some edifices dating back to Roman times, is bounded by Skobelev boulevard to the west and south-west, and by Vasil Levski Boulevard to the east and southeast. This area measures roughly one kilometer across.

From the middle of NDK Park, one can take Vasil Levski boulevard in a north-easterly direction towards Tsar Osvoboditel Boulevard, which in turn leads us out of Sofia on Tsarigradsko Shose in an easterly direction. It is right at the intersection of Osvoboditel and Levski boulevards that we find what some informants called the 'Grande Dame' of Bulgarian tertiary education institutions, Sofia University (SU) St. Kliment Ohridski.

SU is the oldest (1888) university in Sofia, and in Bulgaria as a whole. This historical legacy is visually represented and reinforced by the imposing size and design of the university's main building at the above-mentioned intersection of two large boulevards.

The main entrance is flanked by six neo-Greek columns, conveying an impression to 
the casual observer of looking quite literally at a 'Temple of higher learning'. While the main SU building on Osvoboditel and Levski boulevards provides the principal visual presence and identification of SU, several of the university departments are housed elsewhere, including a much less visible presence east of the city center, on Tsarigradsko Shose.

Informants from academia and students alike felt that SU is seen as a "classics" university, focusing largely on the humanities, social sciences, and to a lesser extent on natural sciences. Most of these informants felt that the location and architectural style of SU's main building confirms its classics orientation and sets it visually and geographically apart from the other local institutions of higher learning.

SU informants regretted that SU does not have an identifiable, multi-building core campus on which one can stroll around, feeling that adjacent parks provide only an incomplete substitute for a "real" campus. "When walking around SU, you could be anywhere in central Sofia", informant Dessi noted, adding that "I never felt like I was on a university campus". "The closest you get to feeling that you are in a university neighborhood is when you go to the Bibliotheca dance club near SU”, Dessi continued. "There, and in a few nearby cafés, you meet mostly SU students, which gives you a little bit of a feeling that you are in a campus-like environment."

SU informant Nik noted that "Unless you go out in the evening in the area around Ulitsa Shishman in the center of town and meet up with fellow SU students in one of the bars or eateries there, you rarely feel like being in a student neighborhood."

SU Informant Aleks felt that "Since most students don't live around SU and tend to return to their dispersed residences after classes, you don't really get to socialize much unless you make prior arrangements with those whom you know from classes."

Informant comments, therefore, point towards the absence of a well-defined campus having a negative impact on the sustained socializing of SU students, at least across wider circles than their classmates and friends. The same seems to be true for the dispersed location of bars and food outlets around the wider SU neighborhood, which one can roughly identify as the area located between Ulitsa "Tsar Shishman" to the west and Ulitsa "San Stefano" to the east.

This area comprised, at the time of observation, two dance clubs and about ten bars 
frequented by SU students, plus an equal number of comparatively cheap food outlets preferred by students. Students reported that socializing across pre-existing social circles is based entirely on chance encounters in that geographic area.

\section{University space and social capital}

Institutions of higher learning in Sofia are quite dispersed all over the city. While Sofia University is centrally located, close to the government and parliamentary institutions, the Medical University for instance is located west/southwest of the center, and several other universities are grouped in a dedicated educational Studentski Grad neighborhood, located quite a distance towards the southeast from the center. A small campus of the University of Architecture is located to the immediate southeast of the center, while the University of Library Studies is quite isolated in the far southeast of the center, along the main Tsarigradsko Shose thoroughfare, leading to the airport and the city of Plovdiv. The private and comparatively small New Bulgarian University (NBU) is also quite isolated, in a neighborhood to the far southwest of the city center.

This dispersion of the institutions of higher learning across the city space, combined with infrequent public transportation options - if any (NBU for instance had, at the time of my inquiries, not a single bus line running nearby) - does not help in promoting cohesion among Sofia's student populations and in bringing large numbers of students together in one central area at short notice, e.g. for "flash mob" type public action (i.e. action summoned at short notice through social media). NBU, for instance, is located some 8 kilometers (as the crow flies) from the national parliament, while the University of Library Studies is located some 7 kilometers away from the center. All other universities are somewhat closer to the city center, though not necessarily easier and faster to reach by public transportation.

The universities clustered in the "Student City" area to the southeast of the city center, for instance, can be reached either by making a half-hour bus ride or through an equally long (depending on the time of day) combination of bus and subway rides.

Sofia University is located just east, across a small park, of the Bulgarian Parliament and close to several embassies and national government buildings.

Public protests have repeatedly taken place in that park and in other public areas between 
SU and the parliament since the massive 1996 protests against dire economic conditions. Given the proximity of SU to the parliament, SU students were invariably involved in these protests.

Dessi's statements prompt us to examine the other large academic neighborhood of Sofia. Indeed, when driving in a due southerly direction from SU for about five kilometers, we come to the above-mentioned, newer neighborhood of Sofia, called "Student City", an area mostly dating back to an intense construction period between the mid-1960s to the late 1970s.

This neighborhood is home to three technical and natural sciences universities, as well as the other large social sciences university of Sofia, the "University of national and world economy" (UNWE), or Universitet za nationalno y svetovno stopanstvo (UNSS). While this university was founded in 1920, it stayed in the shadow of its SU 'mother' until the mid-1950s.

In fact, from 1947 until 1952 it was integrated into SU as this university's faculty of economic and social sciences. It is only in 1953 that it became the fully autonomous Karl Marx University, a name which it retained until the political and economic regime change in 1990, at which point it became UNWE.

UNWE's buildings are of a typical 1960s and 1970s sober and functional style, clustered around a compact, but well identifiable campus, with some green spaces dotted around it. UNWE is located opposite Studentski Park, which - despite its name - was only sparsely frequented by UNWE students during my core observation period from 2015 to 2018. In fact, Ulitsa "Ossemi Dekemvri", running past the main UNWE entrance, appears to represent more than just a traffic boundary between UNWE and the northern part of Studentski Grad, since most of the bars and food outlets around UNWE are located to the south and the west of Studentski Park.

This spatial distribution of facilities appears to be one of the main causes for the limited socializing between UNWE students and those of the other three universities in Studentski Grad. Indeed, out of all my UNWE informants, few had ever consciously met a student from these three universities, when staying in the Studentski Grad neighborhood. Informant Valery said that "you never see the engineers around UNWE", referring to one of the main teaching specialties of the other three local universities.

Regarding socializing among UNWE students, all informants studying at that university, 
except Valery, lived in one of the student apartments west of UNWE. They agreed that the fact of living in the same building, or in neighboring buildings, was conducive to easier and more frequent socializing among students. Valery felt somewhat excluded from the socializing of UNWE residence-based students and thus was in more frequent touch with friends from preUNWE days than with fellow students. Informants felt that the proximity of dance clubs and bars to the apartment blocks was facilitating meeting up with fellow students for drinks and leisure activities. "When you've had a few drinks, you don't have to walk far to get home," one informant said.

UNWE informants living in Student City walked to and from their student housing facilities, which are all located in an area less than 900 meters from the university campus. Bars and restaurants in the area are also located less than 900 meters from campus and in some instances less than 50 meters from student housing and equally close to the university.

Student walking patterns were usually mono-directional, meaning that they either would walk to and from campus in a single, more or less direct line, either on their housing route (i.e. to and from their apartment) or their socializing route (e.g. to and from bars and restaurants). Rarely would they make a detour from these direct routes, e.g. to campus via a restaurant?

When walking in the UNWE neighborhood, students would do so either alone (less than about 20 percent of the time) or in small groups of up to 5 students (about 75 percent of the time).

Only rarely (about 5 percent of the time) would the groups exceed 5 students, e.g. when most members of a particular UNWE class would walk together to a bar or restaurant for a specific celebration, such as a birthday, or an admission to graduate study at a university, or on the occasion of a job offer for a student.

As regards interaction with SU students, UNWE informants felt that the geographical distance, coupled with inconvenient transportation options - especially at night, made continued socializing with SU students difficult. Informant Delia felt that "SU students live in another world anyway; they regard themselves as superior to us." Informant Chris believed that "Unless you know SU students through common friends or a common activity outside of the university, you rarely meet them." 
"They don't seem to frequent our bars, and we don't go to theirs" she added.

Conversely, SU informants felt that UNWE students live "so far away, that it is impractical to meet them" (Aleks). Dessi likewise felt that "UNWE students are a different crowd". Nik stated that "They (UNWE students) seem to have different interests, though we occasionally see them downtown at night."

Those SU students who happened to live in Studentski Grad hardly interacted with UNWE students, save for those they came across on their floor of a student residence.

Both SU and UNWE students mentioned that during public protests students from both universities came together, but even there they hardly interacted. Some informants pointed out that, although social media played an important role in convening students for public events, such as protest marches, convening usually took place via separate social media pages, even though these pages were published within the same social media platform (mostly Facebook). This indicated that both their virtual and real worlds rarely converged.

\section{Conclusion: Spatial impact on social capital}

Having examined the spatial aspects of student socializing at SU and UNWE, I identified several spatial impacts and consequences for the construction and maintenance of social capital among Sofia students:

1. Given the spatial scattering of SU student accommodation and the absence of a welldelineated core campus, we have seen that the informants from this university socialize mostly at lunchtime and immediately after afternoon classes and generally only for a snack, coffee, or drinks, before returning to their geographically dispersed accommodations.

2. Conversely, UNWE students who live in student cities have a comparatively lively social scene, given the compact nature of the neighborhood where both their apartments and the bars and eateries which they tend to frequent are located. UNWE informants stated that due to living together in a relatively compact neighborhood, they found it easy to form friendships with fellow students - friendships that can continue after university if UNWE graduates find employment in Sofia. 
3. SU informants reported that friendships formed at university were mostly based on the attendance of common courses, rather than living together, with the notable exception of roommates when the latter were not enrolled in common courses, but socialized together, as was the case for Radi with one of her roommates during part of her studies. UNWE informants felt that common courses and common living arrangements facilitated the forming of friendships and that friendships were strengthened by any additionality of these organizational and spatial factors.

4. SU informants stated that due to the proximity of the parliament and other public institutions to the main SU building, they were more easily motivated to participate in, or at least observe, public events around these institutions than if the university was not located in their proximity. Nonetheless, geographic proximity did not prompt them to feel more positively about the parliament or the government.

a. Informants Nik and Boyko were the exceptions, in that both took an early interest in the comings and goings around the parliament building and in the work of some public policy NGOs, in which they became involved later in their studies and their professional careers.

5. UNWE informants felt some geographical isolation from "where things are happening in town", including events around public institutions, such as street protests. They felt that the large size of Borissova Gradina park between Student City and the center of Sofia made them feel "remote", and the circuitous route of the main bus line into town dissuaded them from participating in public events in the center of the city. They felt that Studentski Grad was "not part of the city".

6. Sustained bridging social capital among SU informants appeared less common during the years of their studies than that of UNWE students who lived in Student City, yet SU informants were more likely to participate in public events in central Sofia, in public space near SU, than UNWE students.

7. UNWE informants stated that they rarely discussed "serious issues" during their lunch breaks or after their afternoon classes. They felt that the setting and nature of 
the venues they frequented in Student City were dissuasive for engaging in serious debates.

In light of the above findings, I have tentatively concluded that spatial aspects, both on a macro scale (regional and national) and a micro scale (urban neighborhoods), can have an impact on the maintenance and scope of social capital over time. A larger-scale study of socializing of Sofia students could examine the relative weight of spatial considerations versus other possible influences on social capital characteristics and civic activism, such as group leadership; timing of socializing; personal availability for socializing (especially of those employed parttime), and direct costs of socializing (e.g. cost of frequentation of cafés, restaurants, bars, movie theatres, etc.).

\section{References}

Christaller, W. (1933). Die zentralen Orte in Süddeutschland [The central places in southern Germany], Gustav Fischer Verlag.

Giordano, C., \& Kostova, D. (2013). No wealth without networks and personal trust: New capitalist agrarian entrepreneurs in the Dobrudzha; In G. Duijzings (Ed.), Global villages: rural and urban transformations in contemporary Bulgaria (pp. 105-122). Anthem Press.

Hörschelmann, K., \& Stenning, A. (2008). Ethnographies of postsocialist change. Progress in Human Geography, 32(3), 339-361. https://doi.org/10.1177/0309132508089094

Lawton, L., Silverstein, M., \& Bengtson, V. (1994). Affection, social contact, and geographic distance between adult children and their parents. Journal of Marriage and Family, 56(1), 57-68. doi:10.2307/352701

Rutten, R., Westlund, H., Boekema, F. (2010). The spatial dimension of social capital, European Planning Studies, 18(6), 2010, 863-871.

Von Thünen, J. (1826). Der isolierte staat: beziehung auf landwirtschaft und nationalökonomie [The isolated state: relationship to agriculture and national economy], Gustav Fischer Verlag.

Westlund, H. (1999). An interaction-cost perspective on networks and territory. Annals of Regional Science, 33(1), 93-121. 